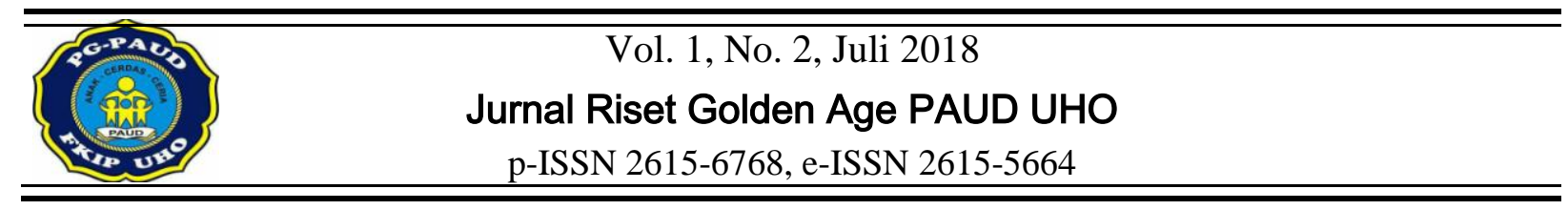

\title{
MENINGKATKAN PENGENALAN RUKUN ISLAM MELALUI MEDIA KARTU BERGAMBAR DI KELOMPOK B SENTRA PERSIAPAN TK KARTIKA XX-46 KOTA KENDARI
}

\author{
Yesti Afriani ${ }^{1)}$, Sri Yuliani M $^{2)}$ \\ ${ }^{1}$ Alumni Jurusan PG-PAUD, Universitas Halu Oleo. Jln. H.E.A Mokodompit, Kendari 93232, \\ Indonesia. \\ ${ }^{2}$ Dosen Jurusan PG-PAUD, Universitas Halu Oleo. Jln. H.E.A Mokodompit, Kendari 93232, \\ Indonesia.
}

\begin{abstract}
Abstrak
Penelitian ini bertujuan untuk meningkatkan pengenalan rukun Islam melalui media kartu bergambar di Kelompok B Sentra Persiapan TK Kartika XX-46 Kota Kendari. Jenis penelitian ini adalah Penelitian Tindakan Kelas (PTK). Penelitian ini dilaksanakan dalam dua siklus. Tahap-tahap dalam penelitian ini mengikuti prosedur, yaitu: perencanaan, pelaksanaan, pengamatan atau observasi, dan refleksi. Subjek dalam penelitian ini adalah guru dan anak di Kelompok B Sentra Persiapan TK Kartika XX-46 Kota Kendari yang berjumlah 20 orang yang terdiri atas 12 orang anak perempuan dan 8 orang anak laki-laki. Berdasarkan hasil tentang pengenalan rukun Islam melalui media kartu bergambar menunjukkan bahwa terdapat peningkatan. Hal ini dapat dibuktikan pada siklus I diperoleh persentase yaitu sebesar $65 \%$ dan pada siklus II diperoleh persentase sebesar $85 \%$. Dengan demikian dapat disimpulkan bahwa pengenalan rukun Islam di kelompok B Sentra Persiapan TK Kartika XX-46 Kendari dapat ditingkatkan melalui media kartu bergambar.
\end{abstract}

Kata kunci: Rukun Islam, Kartu Bergambar, Anak.

\section{IMPROVING INTRODUCTION THE PILLARS OF ISLAM THROUGH PICTURE CARDS MEDIA IN GROUP B SENTRA PREPARATION KARTIKA XX-46 KINDERGARTEN KENDARI CITY}

\begin{abstract}
This research aims to improve recognition the pillars of Islam through picture cards media in group B Sentra Preparation Kartika XX-46 Kindergarten Kendari City. This research is the Classroom Action Research. This research was conducted in two cycles.The stages in this research followed the action research procedure, that's: planning, action, observation or evaluation, and reflection. The subject of the research are teachers and children at Group B Sentra Preparation Kartika XX-46 Kindergarten Kendari City, totaling twenty children consisting of twelve girls and eight sons. Based on the results of the introduction pillars of Islam through picture cards media indicates that there is an increase. This can be evidenced in the first cycle obtained by percentage that is equal to $65 \%$ and the second cycle was obtained percentage of $85 \%$. The research could be concluded that introduction the pillars of Islam in group B Sentra Preparation Kartika XX-46 Kindergarten Kendari could be increase through picture cards media.
\end{abstract}

Keywords: Pillars Of Islam, Picture Cards, Child.

\section{PENDAHULUAN}

Anak usia dini adalah pribadi yang mengalami proses pertumbuhan dan perkembangan yang sangat cepat sesuai dengan sifat alami anak, dan merupakan pribadi yang mempunyai berbagai macam potensi. Potensipotensi itu dirangsang dan dikembangkan agar anak dapat berkembang secara optimal. Oleh karena itu dibutuhkan kondisi atau tempat pendidikan yang sesuai dengan kebutuhan dan perkembangan anak, agar kebutuhan pendidikan tercapai secara optimal.

Undang-undang Sistem Pendidikan Nasional No. 20 Tahun 2003 menyatakan bahwa pendidikan nasional bertujuan untuk mengembangkan potensi peserta didik agar menjadi manusia yang beriman dan bertakwa 
kepada Tuhan Yang Maha Esa, berakhlak mulia, sehat, berilmu, cakap, kreatif, mandiri dan menjadi warga negara yang demokratis serta bertanggung jawab. Taman Kanak-kanak (TK) sebagai salah satu bentuk lembaga pendidikan usia dini, berada pada jalur pendidikan formal sebagaimana tertuang pada pasal 28 ayat (3) bahwa "Pendidikan anak usia dini pada jalur pendidikan formal berbentuk Taman Kanakkanak (TK), Raudlatul Athfal (RA), atau bentuk lain yang sederajat" implikasinya adalah bahwa keberadaan dan penyelenggaraan TK perlu diatur dalam suatu kebijakan tertentu oleh pemerintah dalam hal ini Departemen Nasional.

Upaya yang dapat dilakukan untuk mengembangkan kemampuan penancapan aqidah Islam pada anak usia dini salah satuya adalah dengan membimbing anak dalam mengembangkan kemampuan membaca sejak usia dini. Metode Doman sangat memperhatikan perkembangan linguistic dan penginderaan (visual dan auditory) anak melalui kartu kata (flashcard) sebagai media belajar yang inti dari metode tersebut. Pada metode ini peserta didik tidak dituntut untuk langsung belajar mengeja tetapi langsung diajarkan kata per kata, yang langsung berhubungan dengan kehidupan sehari-hari, seperti; shalat, puasa, zakat, haji.

Nilai agama adalah kemampuan anak untuk menyadari keberadaan tuhan, dimanapun dan kapanpun. Kemudian, kesadaran tersebut berpengaruh terhadap segala perbuatannya sehingga hampir seluruh aktivitas anak dikendalikan oleh kesadaran dalam dirinya (Suyadi, 2015: 13). Menurut Darajat (1984:260), mendefinisikan nilai adalah suatu perangkat keyakinan atau perasaan yang diyakini sebagai suatu identitas yang memberikan corak yang khusus kepada pola pemikiran dan perasaan, keterikatan maupun perilaku.

Menurut Zahidah dalam Andrianto (2013: 36) mengenalkan akhlakul karimah kepada anak semenjak anak berusia dini sangat penting untuk memupuk nilai agama anak. Ada beberapa cara mengenalkan akhlak yang baik pada anak, sebagai berikut.

a. Mengajak anak untuk shalat berjamaah di mesjid maupun di rumah

b. Menepati janji apabila telah berjanji pada anak.

c. Bercerita kisah perjuangan nabi-nabi dalam mengembangkan ajaran islam.

d. Membiasakan anak dengan adab islami dalam kehidupan sehari-hari. e. Membiasakan dan mengajarkan anak membaca Al-Quran.

f. Membiasakan dan mengamalkan bacaan doa sehari-hari.

g. Mengajarkan anak berkata jujur dan santun.

h. Mengajarkan anak untuk menghormati yang lebih tua dan menyayangi yang lebih muda.

Berdasarkan observasi awal yang dilakukan peneliti pada saat berkunjung ke lokasi menunjukan bahwa pengenalan nilai agama anak di kelompok B Sentra Persiapan TK Kartika XX-46 Kendari masih rendah. Rendahnya nilai-nilai agama anak khususnya agama Islam diduga disebabkan karena guru dalam pengenalan agama hanya melalui hafalan doa sehari-hari saja tidak pernah menggunakan media, sehingga keaktifan anak dalam proses pembelajaran agama masih sangat rendah, khususnya pengenalan rukun islam di TK tersebut. Hasil wawancara yang dilakukan dari 20 orang yang terdiri 8 anak laki-laki dan 12 anak perempuan anak hanya 6 orang anak atau hanya mencapai $30 \%$ yang kategori $\mathrm{BSH}$ dalam mengenal agama khususnya rukun islam sedangkan yang lainnya (70\%) masih perlu bimbingan dari gurunya, ini merupakan ketutantasan yang rendah, karena masih dibawah standar yang ditetapkan di sekolah yaitu sebesar $75 \%$.

Jalaluddin (2002: 66) mnegungkapkan perkembangan religiusitas pada usia anak memiliki kerakteristik tersendiri. Perkembangan agama pada anak-anak melalui beberapa 3 fase atau tingkatan:

a. The Fairy Tale Stage (Tingkat Dongeng). Tingkatan ini dimulai pada anak usia 3-6 tahun. Pada tingkatan ini konsep mengenai Tuhan lebih banyak dipengaruhi oleh fantasi dan emosi. Pada tingkat perkembangan ini anak menghayati konsep keTuhanan sesuai dengan tingkat perkembangan inteleknya. Kehidupan masa ini masih banyak dipengaruhi kehidupan fantasi hingga dalam menanggapi agama pun anak masih menggunakan konsep fantatis yang diliputi oleh dongeng-dongeng yang kurang masuk akal.

b. The Realistic Stage (Tingkat Kenyataan). Tingkat ini dimulai sejak 7-12 tahun. Pada fase ini anak mampu memahami konsep ketuhanan secara relistik dan kongkrit. Pada masa ini ide keagamaan pada anak didasarkan atas dorongan emosional, hingga mereka dapat melahirkan konsep Tuhan yang formalis. 
c. The Individual Stage (Tingkat Individu). Tingkat ini terjadi pada usia remaja. Situasi jiwa yang mendukung perkembangan rasa keTuhanan pada usia ini adalah kemampuannya untuk berfikir abstrak dan kesensitifan emosinya. Pemahaman keTuhanan padan remaja dapat ditekankan pada makna dan keberadaan Tuhan bagi kehidupan manusia.

Kesadaran beragama pada usia ini ditandai dengan ciri-ciri sebagai berikut: (a) sikap keagamaannya bersifat reseptif (menerima) meskipunbanyak bertanya, (b) pandangan ketuhanannya bersifat dipersonifikasikan, (c) penghayatan secara rohaniah masih superficial (belum mendalam) meskipun mereka telah melakukan atauberpartisipasi dalam berbagai kegiatan ritual, (d) hal ketuhanan dipahamkan secara ideosyncritic (menurut khayalan pribadinya) sesuai dengan taraf berpikirnya yangmasih bersifat egosentrik.

Yang termasuk rukun Islam itu ada lima, yaitu :

a) Mengucapkan dua kalimat syahadat, yaitu mengakui bahwa Allah itu Esa dan mengakui adanya utusannya, yaitu Nabi Muhammad Saw.

b) Mendirikan sholat wajib, yaitu suatu ibadah menyembah kepada Allah. Sholat menurut bahasa adalah do'a, sedangkan menurut istilah yaitu suatu amalan yang terdiri dari perkataan dan perbuatan, yang diawali dengan takbiratul ihram dan diakhiri ucapan salam dengan syarat rukun yang telah ditentukan.

c) Membayar zakat, yaitu mengeluarkan sebagian dari harta untuk dibagikan kepada yang telah berhak menerimanya.

d) Menjalankan puasa Ramadhan, yaitu meninggalkan makan dan minum dan sebagainya, yang bisa membatalkannya mulai dari terbitnya fajar hingga terbenamnya sang matahari.

e) Mengerjakan haji bagi yang mampu, yaitu menjalankan ibadah dan umrah disekeliling Masjidil Haram di Mekah

(Labib dan Ridha'ie, 2009: 9)

Kartu merupakan alat media yang membantu menggunakan indra penglihatan dominan dan juga alat yang memperjelas pengertian dan gambar. Sedangkan gambar adalah suatu bentuk fungsi semiotik yang dapat di anggap sebagai separuh jalan antara permainan simbolik dan citra mental. Gambar dapat dikatakan seperti permainan simbolik dalam fungsinya untuk memberikan kesenangan dan autotelisme dan seperti citra mental dalam upayanya meniru kenyataan.

Gambar mempunyai banyak kelebihan antara lain: (1) gambar dapat mengatasi batasan ruang dan waktu. Tidak semua benda, objek, atau peristiwa dapat dibawa ke kelas, dan tidak selalu bisa siswa dapat melihat objek atau peristiwa tertentu; (2) gambar dapat mengatasi keterbatasan pengamatan kita; (3) harga relatif murah, gampang didapat dan bersifat konkret sehingga berbagai macam persepsi tentang sesuatu dapat dilihat di dalam gambar.

Kartu bergambar merupakan media yang mempunyai peranan penting untuk memperjelas pengertian dan gambar dapat di hindarkan kesalahan pengertian antara apa yang dimaksud oleh guru dengan apa yang di tangkap oleh siswa (Ula, 2011: 16).

\section{METODE}

Jenis penelitian yang digunakan dalam penelitian ini adalah Penelitian Tindakan Kelas (Classroom Action Research). Penelitian Tindakan Kelas adalah pencermatan yang dilakukan oleh orang-orang yang terlibat didalamnya (guru, peserta didik, kepala sekolah) dengan menggunakan metode refleksi diri dan bertujuan untuk melakukan perbaikan diberbagai aspek pembelajaran (Suyadi, 2012: 22).

Lokasi penelitian ini akan dilaksanakan di kelompok B Sentra PersiapanTK Kartika XX-46 Kendari. Waktu penelitian ini dilaksanakan pada bulan april 2016 sampai bulan mei 2016 yaitu semester genap tahun pelajaran 2015/2016. Subjek dalam penelitian ini adalah guru dan anak didik pada kelompok B sentra persiapan TK Kartika XX-46 Kendari yang berjumlah 20 orang yang terdiri atas 12 orang anak perempuan dan 8 orang anak laki-laki dengan rentangan usia 5-6 tahun.

Faktor-faktor yang diteliti dan diamati dalam penelitian ini adalah sebagai berikut: (1) faktor anak didik kelompok B Sentra Persiapan TK Kartika XX-46 Kendari melakukan aktivitas kegiatan belajar dan meningkatan pengenalan rukun Islam melalui media kartu bergambaryang berupa menyebutkan jumlah rukun Islam, mengurutkan rukun Islam, mencocokkan rukun Islamdan memasangkan rukun Islam sesuai pasangannyadi kelompok B Sentra Persiapan TK Kartika XX-46 Kendari; (2) faktor guru, mengamati aktivitas guru dan proses 
pembelajaran dalam upaya meningkatan pengenalan rukun Islam melalui media kartu bergambar di kelompok B Sentra Persiapan TK Kartika XX-46 Kendari; (3) hasil belajar anak tentang pengenalan rukun Islam dengan menggunakan media kartu bergambar.

Prosedur penelitian tindakan kelas ini terdiri dari dua siklus. Setiap siklus terdiri dari tiga pertemuan yang dilaksanakan berdasarkan tujuan yang ingin dicapai pada setiap faktor yang akan diamati. Tahapan penelitian dalam tindakan kelas adalah perencanaan, pelaksanaan, observasi/pengamatan, dan refleksi.

Teknik pengumpulan data dalam penelitian ini meliputi: (1) teknik observasi adalah cara pengumpulan data untuk mendapatkan informasi melalui pengamatan langsung terhadap sikap dan perilaku siswa. Aspek yang diobservasi dan hasilnya bervariasi, tergantung tujuan penilaian. Pengamatan ini dapat dilaksanakan dengan pedoman pengamatan (format, daftar cek), catatan lapangan, jurnal harian, observasi aktivitas di kelas, penggambaran interaksi dalam kelas, alat perekam elektronik, atau pemetaan kelas; (2) wawancara adalah suatu tehnik pengumpulan data yang dapat dilakukan guru untuk mendapatkan informasi tentang perkembangan dan permasalahan anak dengan cara melakukan percakapan langsung, baik dengan anak maupun orang tua. Dengan wawancara, guru dapa menggali lebih jauh kondisi objektif anak, (3) Teknik dokumentasi yang digunakan dalam penelitian ini adalah dengan mengambil gambar pada saat anak melakukan proses pembelajaran. Gambar ini berupa foto yang dapat menggambarkan secara nyata ketika anak beraktivitas pada pembelajaran, dengan menggunakan media kartu kata bergambar. Selain itu, foto-foto yang diperoleh dapat menjadi pelengkap data, guna menyempurnakan penelitian yang dilakukan. Ada berbagai dokumen yang dapat membantu peneliti dalam mengumpulkan data penelitian yang ada relevansinya dengan permasalahan dalam penelitian tindakan kelas, seperti silabus dan RPP, laporan-laporan diskusi, berbagai macam hasil ujian dan tes, laporan rapat (Kunandar, 2012).

Teknik analisis data yang digunakan adalah dengan menggunakan analisis deskriptif. Metode analisis deskriptif adalah metode yang menjelaskan atau menggambarkan fenomena penelitian secara objektif. Dalam menganalisis data dan memberi penilaian pada setiap indikator aspek pengamatan, peneliti menggunakan kriteria penilaian yang selama ini digunakan oleh guru taman kanak-kanak untuk menilai kemampuan pengenalan rukun Islam anak dalam kegiatan pembelajaran melalui media kartu bergambar rukunIslam di TK Kartika XX-46 Kendari.

Selain itu juga mengacu pada pedoman pemberian penilaian dalam satuan pendidikan di TK, yaitu dengan penilaian secara kualitatif atau dengan memberikan nilai dalam bentuk simbol bintang seperti: $*=$ Belum Berkembang (BB), $* *=$ Mulai Berkembang $(\mathrm{MB}),{ }^{* * *}=$ Berkembang Sesuai Harapan (BSH), dan **** = Berkembang Sangan Baik (BSB) (Depdiknas, 2004:26).

Indikator keberhasilan dalam penelitian ini terdiri dari indikator proses dan indikator hasil (nilai) anak didik. Apabila rencana kegiatan pembelajaran terlaksana minimal $75 \%$ baik secara individual maupun klasikal di kelompok B Sentra Persiapan TK Kartika XX46 Kendari yaitu dengan mencapai nilai Berkembang Sesuai Harapan (BSH) dan Berkembang Sangat Baik (BSB) maka pelaksanaannya dikatakan berhasil.

\section{HASIL DAN PEMBAHASAN}

Langkah awal yang dilakukan peneliti sebelum melaksanakan penelitian tindakan kelas, yaitu peneliti melakukan pengamatan awal terhadap kegiatan pembelajaran sebelum adanya tindakan tanpa mengganggu proses pembelajaran untuk mengetahui keadaan awal pengenalan rukun Islam. Berdasarkan hasil pengamatan awal dan wawancara yang dilakukan menunjukkan bahwa pengenalan rukun Islam anak di kelompok B TK Kartika XX-46 masih perlu dikembangkan dan ditingkatkan lagi karena masih berada pada kategori Mulai Berkembang (MB) atau dengan simbol nilai bintang dua (**). Hal ini dibuktikan dengan hasil wawancara dengan guru kelompok B sentra persiapan mengenai pengenalan rukun Islam anak yang menyatakan bahwarata-rata anak memiliki perolehan nilai bintang dua $(* *)$ atau Mulai Berkembang (MB) yang diperoleh oleh 12 orang anak didik atau sebesar $60 \%$, dengan kata lain sebagian besar anak didik belum mampu memenuhi target ketercapaian dalam indikator keberhasilan dalam kegiatan penilaian sehingga hal ini perlu diberikan bantuan secara langsung dan bimbingan secara menyeluruh pada kegiatan tersebut, dan ada 5 orang anak didik memperoleh nilai bintang tiga 
(***) atau Berkembang Sesuai Harapan (BSH) atau sebesar $25 \%$ dan 3 orang anak didik yang memperoleh nilai bintang satu (*) atau Belum berkembang (BB) atau sebesar $15 \%$.

Hasil observasi awal tersebut menjadi pijakan bagi peneliti untuk merumuskan kembali dengan guru sentra persiapan untuk menerapkan kegiatan pembelajaran dalam rangka pengenalan rukun Islam melalui media kartu bergambar pada tindakan Siklus I.

Hasil analisis observasi guru sesuai dengan lembar observasi sebanyak 11 aspek yang diamati yang harus dicapai oleh guru. Pada siklus I skor yang dicapai oleh guru dari 11 aspek hanya 9 aspek (81.8\%) diantaranya: (1) guru merencanakan pembelajaran pengenalan rukun Islam anak dengan menggunakan media kartu kata bergambar; (2) guru menyediakan alat/bahan yang diperlukan dalam pembelajaran pengenalan rukun Islam; (3) guru memotivasi anak untuk belajar dengan menggunakan media kartu bergambar rukun Islam; (4) guru meminta anak menyebutkan jumlah rukun Islam; (5) guru menjelaskan materi tentang penggunaan media kartu bergambar rukun Islam yang akan diajarkan pada anak; (6) guru bertanya tentang masalah-masalah yang akan dihadapi oleh anak dalam penggunaan media kartu bergambar rukun Islam; (7) guru meminta anak bermain memasangkan kartu bergambar rukun islam sesuai pasangannya; (8) guru membimbing anak dalam penggunaan media kartu bergambar rukun Islam; dan (9) guru mengadakan tanya jawab tentang rukun Islam. Sedangkan yang tidak tercapai sebanyak 2 aspek (18.20\%) diantaranya: (1) guru menyampaikan materi pembelajaran tentang pengenalan rukun Islam. dan (2) guru memperlihatkan media kartu bergambar rukun Islam.

Analisis hasil observasi anak sesuai dengan lembar observasi pada siklus I sebanyak 10 aspek yang diamati diharapkan tercapai, namun yang tercapai sebanyak 8 aspek $(80 \%)$ diantaranya: (1) perhatian anak tertuju pada proses pembelajaran; (2) anak mengikuti arahan guru untuk belajar dengan menggunakan media kartu bergambar rukun Islam; (3) anak dapat mengetahui tentang rukun Islam, (4) anak menyebutkan jumlah rukun Islam; (5) anak dapat menggunakan media yang disiapkan oleh guru; (6) anak bermain memasangkan kartu bergambar rukun islam sesuai pasangannya; (7) anak berani mengemukakan pendapat sendiri; (8) anak dapat melaksanakan tugasnya sampai selesai sesuai dengan waktu yang diberikan dalam suasana bermain sambil belajar. Sedangkan yang tidak tercapai sebanyak 2 aspek (20\%) diantaranya: (1) Mengadakan tanya jawab dengan guru tentang rukun Islam; (2) anak dapat merespon penjelasan guru mengenai penggunaan media kartu bergambar rukun Islam.

Analisis keberhasilan tindakan secara klasikal pada siklus I diperoleh hasil seperti tampak pada Tabel 1 berikut.

Tabel 1. Perhitungan Nilai Klasikal pada Siklus I

\begin{tabular}{ccc}
\hline Kategori & Jumlah & Persentase \\
\hline $\begin{array}{c}\text { Berkembang Sangat } \\
\text { Baik (BSB) }\end{array}$ & 2 & $10 \%$ \\
\hline $\begin{array}{c}\text { Berkembang Sesuai } \\
\text { Harapan (BSH) }\end{array}$ & 11 & $55 \%$ \\
\hline $\begin{array}{c}\text { Mulai Berkembang } \\
\text { (MB) }\end{array}$ & 5 & $25 \%$ \\
\hline $\begin{array}{c}\text { Belum Berkembang } \\
\text { (BB) }\end{array}$ & 2 & $10 \%$ \\
\hline Jumlah & 20 & $100 \%$ \\
\hline
\end{tabular}

Berdasarkan hasil yang diperoleh pada Tabel 1 terlihat bahwa secara klasikal kegiatan pengenalan rukun Islam melalui media kartu bergambar di kelompok B Sentra Persiapan TK Kartika XX-46 Kota Kendari pada tahap evaluasi siklus I, rata-rata anak didik memperoleh nilai bintang tiga $(* * *)$ atau Berkembang Sesuai Harapan (BSH) dengan persentase $55 \%$ yaitu 11 orang anak didik dari 20 orang anak secara keseluruhan. Nilai bintang empat (****) atau berkembang Sangat Baik (BSB) dengan persentase $10 \%$ yaitu diperoleh 2 orang anak didik, untuk nilai bintang dua $(* *)$ atau mulai berkembang (MB) dengan persentase $25 \%$ yaitu diperoleh 5 orang anak didik dan nilai bintang satu $(*)$ atau belum berkembang (BB) dengan persentase $10 \%$ yaitu diperoleh 2 orang anak didik .

Program kegiatan dalam pengenalan rukun Islam melalui media kartu bergambar di kelompok B Sentra Persiapan TK Kartika XX46 Kota Kendari secara klasikal pada siklus I mencapai tingkat keberhasilan sebesar $65 \%$ yang dicapai dari 20 orang anak didik, dimana 2 orang anak memperoleh nilai bintang empat (****) atau berkembang Sangat Baik (BSB) dengan persentase $10 \%$ dan 11 orang anak memperoleh nilai bintang tiga $(* * *)$ atau Berkembang Sesuai Harapan (BSH) dengan persentase $55 \%$. Hal ini tentu saja akan dihubungkan dengan indikator kinerja yang 
ditetapkan yaitu jika anak didik mencapai tingkat perolehan nilai keberhasilan sebesar 75\%. Tindakan siklus I yang dilaksanakan hanya mencapai perolehan nilai sebesar $65 \%$, maka dapat dikatakan bahwa penelitian tindakan ini belum terselesaikan dan hal ini akan dilanjutkan pada tahapan siklus selanjutnya yaitu siklus II.

Hasil analisis observasi guru sesuai dengan lembar observasi sebanyak 11 aspek yang diamati yang harus dicapai oleh guru. Pada siklus II skor yang dicapai oleh guru dari 11 aspek hanya 10 aspek (90.9\%) diantaranya: (1) guru merencanakan pembelajaran pengenalan rukun Islam anak dengan menggunakan media kartu bergambar; (2) guru menyediakan alat/bahan yang diperlukan dalam pembelajaran pengenalan rukun Islam; (3) guru memotivasi anak untuk belajar dengan menggunakan media kartu bergambar rukun Islam; (4) guru meminta anak menyebutkan jumlah rukun Islam; (5) guru menjelaskan materi tentang penggunaan media kartu bergambar rukun Islam yang akan diajarkan pada anak; (6) guru memperlihatkan media kartu bergambar rukun Islam; (7) guru bertanya tentang masalah-masalah yang akan dihadapi oleh anak dalam penggunaan media kartu bergambar rukun Islam; (8) guru meminta anak bermain memasangkan kartu bergambar rukun islam sesuai pasangannya; (9) guru membimbing anak dalam penggunaan media kartu bergambar rukun Islam; dan (10) guru mengadakan tanya jawab tentang rukun Islam. Sedangkan yang tidak tercapai sebanyak 1 aspek $(9.10 \%)$ yaitu: guru menyampaikan materi pembelajaran tentang pengenalan rukun Islam.

Analisis hasil observasi anak sesuai dengan lembar observasi pada siklus I sebanyak 10 aspek yang diamati diharapkan tercapai, namun yang tercapai sebanyak 9 aspek (90\%) diantaranya: (1) perhatian anak tertuju pada proses pembelajaran; (2) anak dapat merespon penjelasan guru mengenai penggunaan media kartu bergambar rukun Islam; (3) anak mengikuti arahan guru untuk belajar dengan menggunakan media kartu bergambar rukun Islam; (4) anak dapat mengetahui tentang rukun Islam, (5) anak menyebutkan jumlah rukun Islam; (6) anak dapat menggunakan media yang disiapkan oleh guru; (7) anak bermain memasangkan kartu bergambar rukun islam sesuai pasangannya; (8) anak dapat melaksanakan tugasnya sampai selesai sesuai dengan waktu yang diberikan dalam suasana bermain sambil belajar; (9) mengadakan tanya jawab dengan guru tentang rukun Islam; Sedangkan yang tidak tercapai sebanyak 1 aspek $(10 \%)$ yaitu:anak berani mengemukakan pendapat sendiri.

Tingkat keberhasilan anak didik secara klasikal untuk siklus II dapat dilihat pada Tabel 2 berikut ini.

Tabel 1. Perhitungan Nilai Klasikal pada Siklus II

\begin{tabular}{ccc}
\hline Kategori & Jumlah & Persentase \\
\hline $\begin{array}{c}\text { Berkembang Sangat } \\
\text { Baik (BSB) }\end{array}$ & 3 & $15 \%$ \\
\hline $\begin{array}{c}\text { Berkembang Sesuai } \\
\text { Harapan (BSH) }\end{array}$ & 14 & $70 \%$ \\
\hline $\begin{array}{c}\text { Mulai Berkembang } \\
\text { (MB) }\end{array}$ & 3 & $15 \%$ \\
\hline $\begin{array}{c}\text { Belum Berkembang } \\
\text { (BB) }\end{array}$ & 0 & $0 \%$ \\
\hline Jumlah & 20 & $100 \%$ \\
\hline
\end{tabular}

Berdasarkan data hasil perolehan nilai anak didik yang ditampilkan pada Tabel 2 di atas, maka dapat disimpulkan bahwa secara klasikal perolehan nilai anak didik dalam kegiatan pengenalan rukun Islam melalui media kartu bergambar di kelompok B Sentra Persiapan TK Kartika XX-46 Kota Kendari mengalami peningkatan, karena tingkat keberhasilan anak didik yaitu sebesar $85 \%$. Anak didik yang memperoleh nilai bintang empat (****) atau Berkembang Sangat Baik (BSB) yaitu sebanyak 3 orang anak didik dengan persentase $15 \%$, nilai bintang tiga $(* * *)$ atau Berkembang Sesuai Harapan (BSH) yaitu sebanyak 14 orang anak didik dengan persentase $70 \%$, untuk yang memperoleh nilai bintang dua (**) atau Mulai Berkembang (MB) yaitu sebanyak 3 orang anak didik dengan persentase $15 \%$.

Walaupun masih terdapat anak didik yang memperoleh nilai bintang dua $(* *)$ atau Mulai Berkembang (MB) tetapi dapat dikatakan bahwa sebagian besar anak didik dipandang telah mampu menyelesaikan tugas-tugas yang telah ditetapkan sesuai dengan indikator penilaian dalam penelitian ini khususnya dalam pelaksanaan tindakan siklus II. Selain itu dengan perolehan nilai sebesar $85 \%$ tersebut telah dicapai oleh 20 orang anak didik, sehingga secara umum dapat dikatakan bahwa program kegiatan atau rangkaian pelaksanaan pembelajaran dalam pengenalan rukun Islam melalui media kartu bergambar di kelompok B 
Sentra Persiapan TK Kartika XX-46 Kota Kendari dipandang telah terselesaikan dan mencapai tingkat keberhasilan dan sesuai dengan indikator kinerja dan keberhasilan yang telah ditetapkan dalam penelitian ini yaitu jika secara kalsikal perolehan nilai keberhasilan anak didik minimal mencapai $75 \%$ atau anak berada pada rentang nilai $1.50-3.49$.

Hasil yang diperoleh terhadap kegiatan pengenalan rukun Islam melalui media kartu bergambar pada observasi awal jika dibandingkan dengan pelaksanaan siklus I terlihat adanya peningkatan, namun belum mencapai indikator kinerja yang diharapkan, sehingga perlu dilaksanakan siklus II. Hal ini disebabkan pada pelaksanaan siklus I terdapat beberapa kelemahan guru dalam proses pembelajaran dengan menggunakan media kartu bergambar, sehingga perlu dilakukan suatu perbaikan pada siklus II agar indikator kinerja yang diharapkan dapat tercapai. Kelemahan yang terdapat pada siklus I antara lain:

1) Guru masih kurang dalam menyampaikan tujuan pembelajaran yang dilakukan.

2) Guru tidak mengorganisir waktu belajar sesuai dengan apa yang telah direncanakan pada skenario pembelajaran.

3) Guru masih canggung dalam pelaksanaan kegiatan pembelajaran.

Berdasarkan hasil refleksi tersebut kemudian dilakukan langkah-langkah perbaikan pada Siklus II sebagai berikut:

1) Guru sudah menyampaikan tujuan pembelajaran yang dilakukan;

2) Selama kegiatan pembelajaran berlangsung, guru sudah dapat mengorganisir waktu belajar sesuai dengan apa yang telah direncanakan pada skenario pembelajaran;

3) Guru sudah tidak canggung lagi dalam pelaksanaan kegiatan pembelajaran, sehingga proses pembelajaran dapat berlangsung dengan baik.

Setelah dilakukan perbaikan-perbaikan dalam siklus II, ternyata hasil yang diperoleh mengalami peningkatan yang cukup signifikan terhadap kegiatan pengenalan rukun Islam melalui media kartu bergambar. Berdasarkan data yang diperoleh pada siklus I dan siklus II, dapat diketahui perbandingan jumlah anak yang telah mengetaui dan mengenal rukun Islam dengan baik dengan kriteria berkembang sangat baik (BSB) dan berkembang sesuai harapan (BSH), sebelum tindakan atau observasi awal sebanyak 5 anak yang mendapat nilai BSH (Berkembang Sesuai Harapan) dan BSB
(Berkembang Sangat Baik), setelah pelaksanaan siklus I mengalami peningkatan menjadi 13 anak yang mendapat nilai BSH (Berkembang Sesuai Harapan) dan BSB (Berkembang Sangat Baik) dan siklus II meningkat lagi menjadi 17 anak yang mendapat nilai BSH (Berkembang Sesuai Harapan) dan BSB (Berkembang Sangat Baik).

Selama kegiatan penelitian berlangsung, data hasil temuan yang diperoleh sebagaimana dideskripsikan pada halaman sebelumnya, dapat diasumsikan bahwa kegiatan pembelajaran dalam pengenalan rukun Islam melalui media kartu bergambar yang dirancang, disusun dan dilaksanakan secara baik dan optimal oleh peneliti yang bekerjasama dengan guru Sentra Persiapanpada setiap pertemuan siklus I dan siklus II sangat memberikan manfaat pada anak dengan pengalaman langsung, serta kemampuan pengenalan rukun Islam anak menunjukkan peningkatan. Jika dilihat dari pemahaman anak mulai dari pelaksanaan siklus I sebesar $65 \%$ jika dibandingkan pada tahapan observasi awal penelitian yang hanya mencapai $25 \%$ dan pada tindakan siklus II mencapai persentase sebesar $85 \%$, menunjukkan hasil yang lebih baik dari sebelumnya, karena indikator kinerja yang ditetapkan telah tercapai yaitu minimal $75 \%$ maka penelitian ini dapat dihentikan.

\section{KESIMPULAN DAN SARAN}

Berdasarkan hasil penelitian dan pembahasan dapat disimpulkan bahwa media kartu bergambar dapat mengenalkan rukun Islam di kelompok B Sentra Persiapan TK Kartika XX-46 Kota Kendari dengan jumlah anak didik 20 orang yang terdiri dari 8 orang anak laki-laki dan 12 orang anak perempuan. Hal ini ditunjukkan dari adanya peningkatan pada kemampuan pengenalan rukun Islam melalui media kartu bergambar yaitu siklus I diperoleh persentase $65 \%$ atau 13 orang dari 20 anak, dimana ada 2 anak yang mendapat nilai bintang $(* * * *)$ atau Berkembang Sangat Baik (BSB) dan 11 anak yang mendapat nilai bintang $(* * *)$ atau Berkembang Sesuai Harapan (BSH) dan hasil belajar anak pada siklus II diperoleh persentase sebesar $85 \%$ atau 17 orang dari 20 anak, dimana ada 3 anak yang mendapat nilai bintang $(* * * *)$ atau Berkembang Sangat Baik (BSB) dan 14 anak yang mendapat nilai bintang (***) atau Berkembang Sesuai Harapan (BSH).

Peneliti memberi saran yaitu sebaiknya guru menggunakan media kartu bergambar sebagai salah satu cara untuk pengenalan rukun 
Islam karena dari hasil penelitian terbukti bahwa media kartu bergambar dapat mengenalkan rukun Islam kepada anak. Guru memperlihatkan dan menjelaskan media kartu kata bergambar, setelah itu anak menyebutkan rukun Islam secara bersama-sama sebagai wujud pengaplikasian dari proses pembelajaran yang telah dilakukan oleh guru melalui media kartu bergambar.

\section{DAFTAR PUSTAKA}

Andrianto, Tuhana Taufiq. 2013. Cara Cerdas Melejitkan IQ Kreatif Anak. Yogyakarta: Katahati.

Darajat, Zakiah. 1984. Dasar-dasar Agama Islam. Jakarta: Bulan Bintang.

Depdiknas. 2004. Pedoman Penilaian di Taman Kanak-kanak. Jakarta: Depdiknas.

Jalaluddin. 2002. Psikologi Agama. Jakarta: PT Raja Gravindo Persada.

Kunandar. 2012. Langkah Mudah Penelitian Tindakan Kelas Sebagai Pengembangan Profesi Guru. Jakarta: RajaGrafindo Persada

Labib dan Ridha'ie. 2009. Bimbingan Sholat 5 Waktu. Surabaya: Pustaka Agung Harapan Surabaya.

Suyadi. 2012. Buku Panduan Guru Profesional: Penelitian Tindakan Kelas (PTK) dan Penelitian Tindakan Sekolah (PTS). Yogyakarta: Andi.

2015. Cerdas Dengan Spiritual Educational Games. Yogyakarta: Saufa

Ula, Nur Mas. 2011. Efektifitas Media Kartu Gambar Terhadap Peningkatan Kemampuan Bahasa Arab Di Taman Kanak-Kanak Aisiyah Bustanul Athfal 2. Skripsi Mahasiswa Program Studi Psikologi Fakultas Dakwah Institut Agama Islam Negeri Sunan Ampel Surabaya. [Online]. Tersedia: http//digilib.uinsby.ac.id/9277/. [26 Juli 2016].

Undang-Undang Nomor 20 Tahun 2003 Sistem Pendidikan Nasional. Jakarta: Depdiknas. 